\title{
PENGEMBANGAN PERANGKAT PEMBELAJARAN KIMIA MENGGUNAKAN MODEL PEMBELAJARAN KOOPERATIF TIPE NHT BERBASIS REPRESENTASI MAJEMUK (MULTIPLE REPRESENTASI) UNTUK MENINGKATKAN HASIL BELAJAR
}

\author{
Mahmudah'), Suyatno $^{2)}$, Wahono Widodo ${ }^{3)}$ \\ 1)Mahasiswa Program Studi Pendidikan Sains, Program Pascasarjana Universitas Negeri Surabaya \\ ${ }^{2), 3)}$ Dosen Pascasarjana Prodi Pendidikan Sains Univesrtitas Negeri Surabaya \\ E-mail: mahmudahbintisukardi@yahoo.com
}

\begin{abstract}
The purpose of research is to know feasibility of chemistry teaching materials using cooperative learning model NHTbased multiple representations to improve student learning outcomes based on the aspect of validity, practicability, and effectiveness. The teaching materials were developed using the 4-D model while the trial of teaching materials used one group pretest-posttest design. The Teaching materials developed in this research included the lesson plan, student's book, student's worksheet, and achievement test. It were tested to students at class X IPA 3 SMA Negeri 1 Ngadirojo Pacitan. The results showed that: (1) the validity of the developed learning tools valid category included the lesson plan, student's book, student's worksheet, and achievement test; (2) practicability based on readability of student book and student worksheet are good category, feasibility of implementation of the lesson plan are good category, the activity of the students showed that student-centered learning, students responded positively to the learning process; (3) effectiveness based on the results of student learning both from the aspect of attitudes, knowledge, and skills achieve mastery. Based on the above results it can be concluded that the chemistry teaching materials using cooperative learning model NHT-based multiple representations to improve learning outcomes have been valid, practical, and effective, so that feasible to be used in learning process.
\end{abstract}

\section{Keywords: Development Of Teaching Materials, Cooperative Learning Model of NHT Type, Multiple Representations}

Abstrak: Penelitian ini bertujuan untuk mengetahui kelayakan perangkat pembelajaran kimia menggunakan model pembelajaran kooperatif tipe NHT berbasis representasi majemuk untuk meningkatkan hasil belajar siswa berdasarkan aspek validitas, kepraktisan, dan keefektifan. Pengembangan perangkat pembelajaran mengikuti model 4-D dengan uji coba menggunakan rancangan one group pretest-posttest design. Perangkat pembelajaran yang dikembangkan dalam penelitian ini meliputi Rencana Pelaksanaan Pembelajaran (RPP), Buku Ajar Siswa (BAS), Lembar Kerja Siswa (LKS), tes hasil belajar. Perangkat pembelajaran tersebut diujicobakan pada siswa kelas X IPA 3 SMA Negeri 1 Ngadirojo Pacitan. Hasil penelitian menunjukkan bahwa: (1) validitas perangkat pembelajaran yang dikembangkan berkategori valid meliputi RPP, BAS, LKS dan tes hasil belajar; (2) kepraktisan ditinjau dari keterbacaan BAS dan LKS digolongkan baik, keterlaksanaan Rencana Pelaksaanaan Pembelajaran (RPP) berkategori baik, aktivitas siswa menunjukkan bahwa pembelajaran berpusat pada siswa, siswa memberikan respon positif terhadap proses pembelajaran; (3) keefektifan ditinjau dari hasil belajar siswa baik dari aspek sikap, pengetahuan, dan keterampilan mencapai ketuntasan. Berdasarkan hasil penelitian di atas dapat disimpulkan bahwa perangkat pembelajaran kimia menggunakan model pembelajaran kooperatif tipe NHT berbasis representasi majemuk untuk meningkatkan hasil belajar sudah valid, praktis, dan efektif, sehingga layak digunakan dalam pembelajaran.

Kata kunci: Pengembangan Perangkat Pembelajaran, Model Pembelajaran Koopoeratif Tipe NHT, Representasi Majemuk

\section{PENDAHULUAN}

Pendidikan merupakan hal penting dalam kehidupan seseorang. Setiap orang pasti akan memperoleh pendidikan dalam kehidupannya. Berdasarkan Peraturan Pemerintah No 32 tahun 2013 pasal 19 ayat 1, bahwa proses belajar dalam satuan pendidikan diselenggarakan secara interaktif, inspiratif, menyenangkan menantang, memotivasi siswa untuk berpartisipasi aktif, serta memberikan ruang yang cukup bagi prakarsa, kreativitas, dan kemandirian sesuai dengan bakat minat, dan perkembangan fisik, serta psikologis siswa. Kimia adalah ilmu yang mencari jawaban atas apa, mengapa dan bagaimana gejalagejala alam yang berkaitan dengan komposisi, struktur dan sifat, perubahan, dinamika, dan energitika zat. Ikatan kimia merupakan salah satu materi pelajaran 
kimia di SMA yang memuat representasi makroskopis, mikroskopis dan simbolik secara bersamaan. Representasi makroskopis dapat diperoleh melalui pengamatan nyata bentuk senyawa-senyawa yang berkaitan tersebut dan pengalaman siswa sehari-hari. Permasalahan yang dihadapi siswa adalah kesulitan dalam memahami materi pelajaran. Hambatan pada pemahaman konsep kimia bukan karena kesulitan pemahaman terhadap ketiga aspek representasi kimia, namun sebagian besar guru mengajarkan konsepkonsep kimia hanya cenderung pada tingkat representasi makroskopis (menghafal fakta) dan level simbolik. Penelitian Laliyo (2011) menunjukkan bahwa faktor penyebab kerancuan pemahaman konsep siswa pada pokok bahasan materi dan perubahan wujud materi disebabkan oleh pembelajaran lebih didominasi oleh representasi simbolik dan jarang sekali ada kaitan konseptual dengan representasi kimia yang lainnya.

Ikatan kimia merupakan salah satu materi pelajaran kimia di kelas $\mathrm{X}$ yang dianggap sulit oleh siswa. Hal ini diketahui berdasarkan observasi yang dilakukan oleh peneliti terhadap siswa SMA Negeri 1 Ngadirojo Pacitan program IPA. Sebanyak $71,88 \%$ siswa mengganggap materi ikatan kimia sebagai materi yang sulit. Materi sulit pilihan siswa ini didukung berdasarkan wawancara dengan guru kimia di sekolah tersebut, yang menyatakan bahwa pemahaman siswa terhadap materi ikatan kimia masih kurang.

Salah satu model pembelajaran yang menurut peneliti dapat diterapkan untuk membantu siswa mencapai tujuan pembelajaran yang menekankan pada keterampilan bekerja sama untuk memahami suatu konsep adalah model pembelajaran kooperatif. Model pembelajaran kooperatif merupakan suatu model pengajaran dimana siswa belajar dalam kelompokkelompok kecil yang memiliki tingkat kemampuan yang berbeda. Menggunakan pembelajaran kooperatif merubah peran guru dari peran yang berpusat pada guru kepengelolaan siswa dalam kelompok-kelompok kecil. Salah satu tipe pembelajaran kooperatif yang dapat membangun kerjasama antar siswa dan mendorong partisipasi mereka dalam kelas adalah model pembelajaran kooperatif tipe NHT (Numbered Head Together). Model pembelajaran kooperatif tipe NHT dikembangkan oleh Spencer Kagan. NHT memberikan kesempatan kepada siswa untuk saling membagikan ide-ide dan mempertimbangkan jawaban yang paling tepat. Selain itu juga dapat mendorong siswa untuk meningkatkan kerjasama mereka (Suyanti, 2010). Penerapan model pembelajaran kooperatif tipe NHT dengan menggunakan strategi representasi majemuk diharapkan dapat meningkatkan hasil belajar siswa.

Penggunaan aspek representasi majemuk sangat diperlukan guru dalam proses pembelajaran kimia di kelas. Guru hendaknya merancang model pembelajaran dengan mengimplementasikan aspek representasi majemuk, agar efektivitas model pembelajaran yang digunakan meningkat. Dalam penelitian ini peneliti mengkombinasikan penggunaan aspek representasi majemuk dengan model pembelajaran kooperatif tipe NHT karena materi pokok ikatan kimia bersifat abstrak, dengan model pembelajaran kooperatif NHT saja tingkat pemahaman siswa belum optimum sehingga perlu dikombinasikan dengan representasi majemuk.

Tujuan Penelitian ini adalah: Mendeskripsikan validitas perangakat pembelajaran (RPP, Lembar Kerja Siswa, Buku Ajar Siswa, dan Tes Hasil Belajar) pada materi ikatan kimia di SMA dengan menggunakan model pembelajaran kooperatif NHT berbasis representasi majemuk.

Mendeskripsikan kepraktisan perangkat pembelajaran ditinjau dari tingkat keterbacaan Buku Ajar Siswa dan Lembar Kerja Siswa menggunakan model pembelajaran kooperatif NHT berbasis representasi majemuk, keterlaksanaan pembelajaran kimia pada materi ikatan kimia di SMA menggunakan perangkat pembelajaran dengan menggunakan model pembelajaran kooperatif NHT berbasis representasi majemuk, aktivitas siswa selama penerapan perangkat pembelajaran kimia pada materi ikatan kimia di SMA dengan menggunakan model pembelajaran kooperatif NHT berbasis representasi majemuk, respon siswa terhadap pembelajaran kimia pada materi ikatan kimia di SMA dengan menggunakan model pembelajaran kooperatif NHT berbasis representasi majemuk, dan hambatan yang terjadi selama kegiatan pembelajaran ikatan kimia di SMA dengan menggunakan model pembelajaran kooperatif NHT berbasis representasi majemuk berlangsung. Mendiskripsikan keefektifan perangkat pembelajaran ikatan kimia di SMA dengan menggunakan model pembelajaran kooperatif NHT berbasis representasi majemuk ditinjau dari ketuntasan hasil belajar ikatan kimia.

Menurut Farida (2011), representasi majemuk berfungsi sebagai instrumen untuk memberikan dukungan dan memfasilitasi terjadinya belajar bermakna dan belajar mendalam. Dengan menggunakan representasi berbeda dan mode pembelajaran berbeda dapat membuat konsep-konsep menjadi lebih mudah dipahami, menyenangkan, dan bermanfaat (intelligible, plausible, dan fruitful) sehingga dapat meningkatkan motivasi siswar untuk belajar sains.

Teori-Teori Pendukung Pembelajaran Kooperatif Tipe NHT Berbasis Representasi Majemuk antara lain (1) Vygotsky membedakan dua jenis kemampuan yang mencirikan kemampuan anak-anak pada segala tahap perkembangan. Tingkat perkembangan aktual adalah batas atas tugas yang dapat dikerjakan anak secara independen tanpa bantuan orang lain. Tingkat perkembangan potensial adalah batas atas tugas yang 
dapat dikerjakan anak dengan bimbingan seorang individu yang lebih kompeten (Ormrod, 2008).

Vygotsky Ide penting dari teori Vygotsky adalah scaffolding. Scaffolding berarti memberikan kepada seorang anak sejumlah besar bantuan selama tahaptahap awal pembelajaran kemudian mengurangi bantuan tersebut dan memberikan kesempatan kepada anak tersebut mengambil alih tanggung jawab yang semakin besar segera setelah ia dapat melakukannya (Slavin, 1994). (3) Dual Coding Theory (DCT), kognitif menurut DCT melibatkan aktivitas dua subsistem yang berbeda, sistem verbal khusus digunakan untuk berhadapan langsung dengan bahasa dan sistem nonverbal (gambar) khusus digunakan untuk menangani objek nonlinguistik dan program. Sistem terdiri dari unit representasi internal disebut logogens seperti teks dan audio serta imagens seperti gambar, animasi, ilustrasi dan bunyi, yang diaktifkan ketika seseorang mengenali, memanipulasi, berpikir tentang kata-kata atau sesuatu. Representasi yang diperlakukan khusus, memungkinkan kita memiliki logogens dan imagens yang berbeda sesuai dengan visual, auditori, dan sentuhan, dan bahasa motorik dan objek. Representasi terhubung ke sistem masukan sensorik dan keluaran respon sehingga secara mandiri atau bersama dapat bertindak sebagai perantara perilaku nonverbal dan verbal. Kegiatan representasional mungkin atau tidak dialami secara sadar sebagai gambaran dan bicara secara batin (Paivio, 2006)

\section{METODE PENELITIAN}

Jenis penelitian ini adalah penelitian pengembangan karena dikembangkan perangkat pembelajaran kimia menggunakan model pembelajaran kooperatif tipe NHT berbasis representasi majemuk untuk meningkatkan hasil belajar siswa. Perangkat yang dikembangkan terdiri dari Rencana Pelaksanaan Pembelajaran (RPP), Buku Ajar Siswa (BAS), Lembar Kegiatan Siswa (LKS), dan Lembar Penilaian (LP). Subyek penelitian adalah perangkat pembelajaran kimia yang telah dikembangkan yang telah dikembangkan yaitu Rencana Pelaksanaan Pembelajaran (RPP), Buku Ajar Siswa (BAS), Lembar Kegiatan Siswa (LKS), dan Lembar Penilaian (LP), dan diterapkan pada 29 siswa kelas X IPA SMA Negeri 1 Ngadirojo Pacitan tahun ajaran 2015/2016. Penelitian ini dilaksanakan dalam tiga tahap, tahap pertama yaitu mulai pendefisian, tahap kedua perancangan pembelajaran ikatan kimia menggunakan model pembelajaran kooperatif tipe NHT berbasis representasi majemuk mulai RPP, LKS, Lembar Penilaian, dan Buku Ajar Siswa, dan tahap ketiga pengembangan perangkat untuk selanjutnya dilakukan validasi kelayakan perangkat.

Teknik pengumpulan data yang digunakan dapat digolongkan menjadi: (1) Validasi pakar (2)
Pengamatan (3) Metode tes (4) Metode angket. Datadata yang telah terkumpul kemudian dilakukan analisis secara kuantitatif. Data validitas perangkat pembelajaran dihitung melalui rata-rata, sedangkan data keterlaksanaan pembelajaran, keterbacaan perangkat pembelajaran, aktivitas siswa, dan respon siswa dihitung melalui persentase. Data hasil belajar siswa dianalisis sesuai Permendikbud No.104 tentang Pedoman Penilaian Hasil Belajar oleh Pendidik.

\section{HASIL PENELITIAN DAN DISKUSI}

\section{A. Validitas Perangkat Pembelajaran}

Nilai validasi rata-rata dari ketiga validator terhadap perangkat pembelajaran yang meliputi RPP, BAS, LKS, tes pengetahuan, dan rubrik penilaian tugas dapat dilihat pada Tabel 1.

Tabel 1. Hasil Validasi Perangkat Pembelajaran

\begin{tabular}{|c|l|c|l|c|}
\hline No & Perangkat & $\begin{array}{c}\text { Nilai } \\
\text { Validasi }\end{array}$ & Kategori & Keterangan \\
\hline 1 & RPP & 3,38 & Valid & $\begin{array}{c}\text { Layak } \\
\text { digunakan } \\
\text { dalam } \\
\text { pembelajaran } \\
\text { setelah } \\
\text { direvisi }\end{array}$ \\
\hline 2 & BAS & 3,36 & Valid \\
\hline 4 & $\begin{array}{l}\text { Tes } \\
\text { Pengetahuan }\end{array}$ & 3,44 & Valid & Valid \\
\hline
\end{tabular}

Berdasarkan validasi yang telah dilakukan oleh validator, maka perangkat pembelajaran dapat digunakan dengan melakukan revisi sesuai dengan saran dan masukan dari validator, sehingga perangkat pembelajaran ini dapat digunakan oleh guru sebagai panduan dalam proses pembelajaran kimia materi ikatan kimia.

\section{B. Keterbacaan Buku Ajas Siswa dan Lembar KLS}

Keterbacaan Buku Ajas Siswa (BAS) dan Lembar Kerja Siswa (LKS) diukur dengan menggunakan angket yang diberikan kepada siswa setelah melakukan seluruh proses pembelajaran untuk memperoleh hasil keterbacaan Buku Ajar Siswa (BAS) dan Lembar Kerja Siswa (LKS). ). Data keterbacaan BAS dan LKS secara visual dapat dilihat pada Gambar 1 dan Gambar 2.

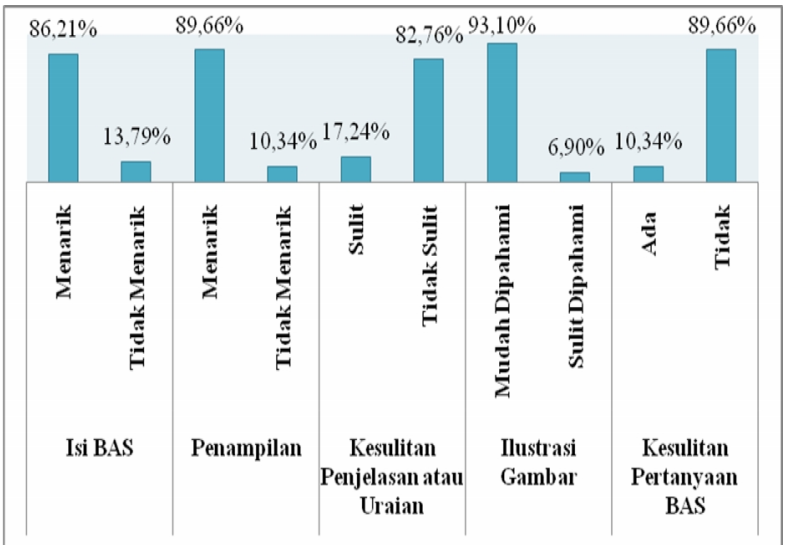

Gambar 1 Diagram Keterbacaan Buku Ajar Siswa (BAS) 


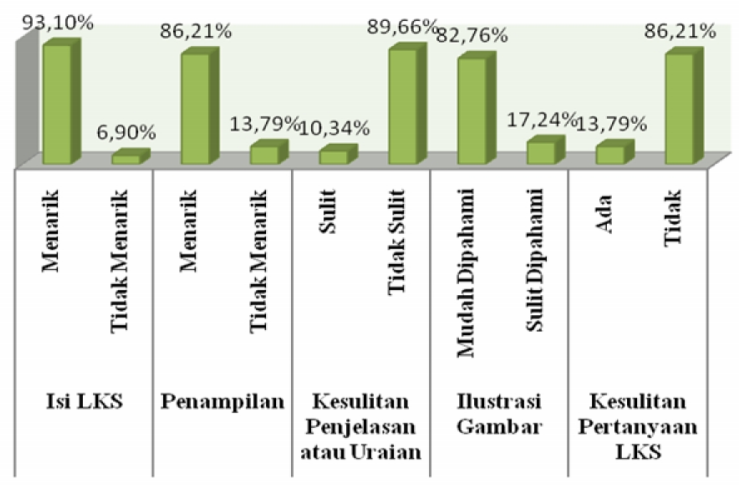

Gambar 2 Diagram Keterbacaan Lembar Kerja Siswa

Penilaian keterbacaan Buku Ajar Siswa (BAS) dan Lembar Kerja Siswa (LKS) diperoleh dari hasil penilaian siswa. Hasil keterbacaan BAS dan LKS dari segi isi dan penampilan secara umum menarik yang berarti siswa tertarik terhadap materi/isi dari BAS dan LKS. Untuk aspek kesulitan penjelasan atau uraian dan ilustrasi gambar, secara umum siswa memberikan jawaban mudah atau tidak sulit artinya uraian dan ilustrasi gambar memudahkan siswa untuk memahami materi. Sementara kesulitan pertanyaan BAS, siswa tidak mengalami kesulitan, artinya siswa dapat menjawab soal-soal dalam buku ajar dengan mudah. Buku Ajar Siswa (BAS)/Lembar Kerja Siswa (LKS) dievaluasi untuk mengetahui keefektifan BAS/LKS dalam mencapai tujuan pembelajaran yang ditargetkan sehingga diketahui kekurangan dan kelemahan BAS/LKS dan pada akhirnya dihasilkan BAS/LKS yang lebih baik dan efektif untuk pembelajaran (Akbar, 2013).

\section{Keterlaksanaan RPP}

Rencana Pelaksanaan Pembelajaran (RPP) disusun berdasarkan Kompetensi Dasar (KD) atau sub tema yang dilaksanakan dalam satu kali pertemuan atau lebih. Setiap pendidik pada satuan pendidikan berkewajiban menyusun RPP secara lengkap dan sistematis agar pembelajaran berlangsung secara interaktif, inspiratif, menyenangkan, menantang, efisien, memotivasi siswa untuk berpartisipasi aktif, serta memberikan ruang yang cukup bagi prakarsa, kreativitas, dan kemandirian, sesuai dengan bakat, minat, dan perkembangan fisik, serta psikologis siswa (Permendikbud No. 65 Tahun 2013).

Keterlaksanaan Rencana Pelaksanaan Pembelajaran (RPP) dapat dilihat dari hasil penelitian keterlaksanaan yang diberikan oleh pengamat, penilaian dilakukan sebanyak empat kali pertemuan yang bertujuan untuk mengetahui keberhasilan guru dalam menerapkan tahap-tahap dalam pembelajaran yang direncanakan, sedangkan aspek pengelolaan suasana kelas meliputi: kesesuaian KBM dengan tujuan pembelajaran, pengelolaan waktu KBM yang digunakan sesuai dengan
RPP, kecenderungan KBM berpusat pada siswa. Hasil pengamatan keterlaksanaan RPP dapat dilihat pada Tabel 2.

Tabel 2. Keterlaksanaan RPP

\begin{tabular}{|c|c|c|c|}
\hline $\begin{array}{c}\text { Pertemuan } \\
\text { ke- }\end{array}$ & \multicolumn{2}{|c|}{ Jumlah Aspek } & Keterlaksana \\
\cline { 2 - 4 } an RPP (\%)
\end{tabular}

Hasil di atas menunjukkan bahwa sintak pembelajaran yang telah dikembangkan terlaksana sepenuhnya.

\section{Aktivitas Siswa}

Hasil pengamatan terhadap aktivitas siswa pada tiap pertemuan dapat dilihat pada gambar 3 .

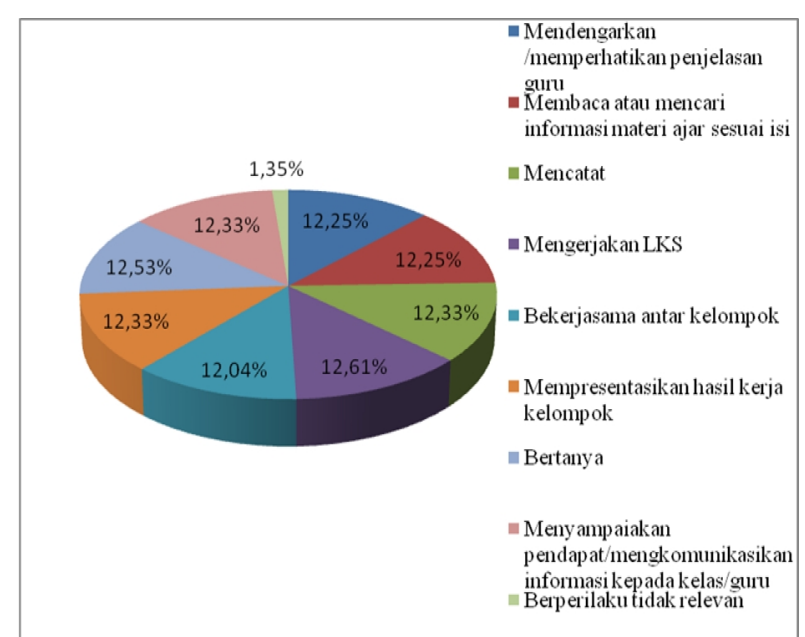

Gambar 3 Data aktivitas siswa

Aktivitas yang menunjukkan keterlibatan aktif siswa yaitu: mendengarkan/memperhatikan penjelasan guru, membaca atau mencari informasi materi ajar sesuai isi, mencatat, mengerjakan LKS, bekerjasama antar kelompok, mempresentasikan hasil kerja kelompok, bertanya, menyampaikan pendapat/mengkomunikasikan informasi kepada kelas/guru. Aktivitas siswa didalam kelas lebih mendominasi dibanding aktivitas guru, yakni sebesar $86,41 \%$. Aktivitas siswa yang paling dominan adalah mengerjakan LKS secara berkelompok. Hal tersebut sesuai dengan tahap ketiga sintaks NHT yaitu berpikir bersama. Data tersebut menunjukkan bahwa pembelajaran kimia menggunakan model pembelajaran kooperatif tipe NHT berbasis representasi majemuk yang dirancang oleh guru sudah berpusat pada siswa (student centered).

\section{Respon Siswa}

Respon dari siswa diperoleh setelah guru melakukan pembelajaran selama empat kali pertemuan, yakni dengan menggunakan angket terhadap pembelajaran yang dilakukan. 
Hasil analisis persentase respon siswa disajikan pada gambar 4.

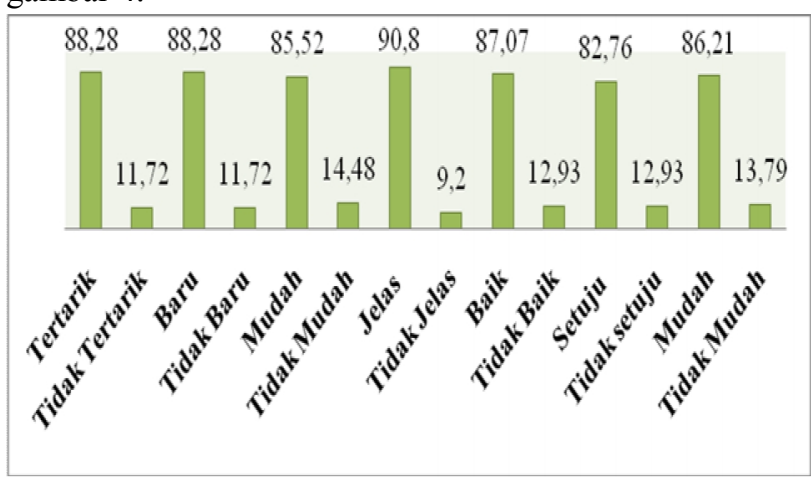

Gambar 4 Grafik Respon Siswa

Keterangan:

Pendapat 1: Katertarikan siswa terhadap komponen pembelajaran

Pendapat 2: Keterbaruan komponen pembelajaran

Pendapat 3: Kemudahan siswa dalam memahami komponen pembelajaran

Pendapat 4: Kejelasan cara mengajar guru dalam membimbing siswa selama KBM

Pendapat 5: Cara guru menggunakan model pembelajaran

kooperatif tipe NHT berbasis representasi majemuk kooperatif tipe NHT berbasis representasi majemuk

Pendapat 6: Kesetujuan siswa bila pelajaran lain jika menerapkan model pembelajaran

Pendapat 7: Kemudahan siswa dalam menjawab butir soal

Berdasarkan grafik di atas, disimpulkan bahwa siswa memberikan respon positif dan baik terhadap ketertarikan, keterbaruan, kemudahan, kejelasan, dan cara guru mengajar menggunakan model pembelajaran kooperatif tipe NHT berbasis representasi majemuk.

\section{Hasil Belajar Siswa}

\section{Kekuatan Aspek Pengetahuan}

Ketuntasan individu untuk aspek pengetahuan ditunjukkan pada Tabel 3.

Tabel 3. Ketuntasan Aspek Sikap

\begin{tabular}{|c|l|l|l|l|l|l|}
\hline \multirow{2}{*}{ No. } & \multicolumn{3}{|c|}{$\begin{array}{c}\text { Ketuntasan Siswa } \\
\text { Pretest }\end{array}$} & \multicolumn{3}{c|}{$\begin{array}{c}\text { Ketuntasan Siswa } \\
\text { Posttest }\end{array}$} \\
\cline { 2 - 7 } & Nilai & Predikat & KET & Nilai & Predikat & KET \\
\hline 1 & 1,08 & D & TT & 3,85 & A- & T \\
\hline 2 & 1,08 & D & TT & 3,38 & B + & T \\
\hline 3 & 1,23 & D + & TT & 3,38 & B + & T \\
\hline 4 & 1,23 & D + & TT & 3,08 & B & T \\
\hline 5 & 1,08 & D & TT & 2,92 & B & T \\
\hline 6 & 1,38 & D + & TT & 3,38 & B + & T \\
\hline 7 & 1,38 & D + & TT & 2,92 & B & T \\
\hline 8 & 1,08 & D & TT & 3,23 & B + & T \\
\hline 9 & 1,23 & D + & TT & 3,38 & B + & T \\
\hline 10 & 1,08 & D & TT & 3,23 & B + & T \\
\hline
\end{tabular}

\begin{tabular}{|c|c|c|c|c|c|c|}
\hline \multirow[t]{2}{*}{ No. } & \multicolumn{3}{|c|}{$\begin{array}{c}\text { Ketuntasan Siswa } \\
\text { Pretest }\end{array}$} & \multicolumn{3}{|c|}{$\begin{array}{c}\text { Ketuntasan Siswa } \\
\text { Posttest }\end{array}$} \\
\hline & Nilai & Predikat & KET & Nilai & Predikat & KET \\
\hline 11 & 1,23 & $\mathrm{D}+$ & TT & 3,54 & A- & $\mathrm{T}$ \\
\hline 12 & 1,08 & D & TT & 3,38 & $\mathrm{~B}+$ & $\mathrm{T}$ \\
\hline 13 & 1,23 & $\mathrm{D}+$ & TT & 3,38 & $\mathrm{~B}+$ & $\mathrm{T}$ \\
\hline 14 & 1,08 & $\mathrm{D}$ & TT & 3,08 & $\mathrm{~B}$ & $\mathrm{~T}$ \\
\hline 15 & 1,23 & $\mathrm{D}+$ & TT & 2,92 & B & $\mathrm{T}$ \\
\hline 16 & 1,23 & $\mathrm{D}+$ & TT & 3,38 & $\mathrm{~B}+$ & $\mathrm{T}$ \\
\hline 17 & 1,23 & $\mathrm{D}+$ & TT & 3,54 & A- & $\mathrm{T}$ \\
\hline 18 & 1,08 & $\mathrm{D}$ & TT & 3,38 & $\mathrm{~B}+$ & $\mathrm{T}$ \\
\hline 19 & 1,08 & D & TT & 3,08 & $\mathrm{~B}$ & $\mathrm{~T}$ \\
\hline 20 & 1,08 & D & TT & 2,92 & B & $\mathrm{T}$ \\
\hline 21 & 1,08 & $\mathrm{D}$ & TT & 3,23 & $\mathrm{~B}+$ & $\mathrm{T}$ \\
\hline 22 & 1,23 & $\mathrm{D}+$ & TT & 3,08 & $\mathrm{~B}$ & $\mathrm{~T}$ \\
\hline 23 & 1,23 & $\mathrm{D}+$ & TT & 3,23 & $\mathrm{~B}+$ & $\mathrm{T}$ \\
\hline 24 & 1,08 & $\mathrm{D}$ & TT & 3,38 & $\mathrm{~B}+$ & $\mathrm{T}$ \\
\hline 25 & 1,38 & $\mathrm{D}+$ & TT & 3,38 & $\mathrm{~B}+$ & $\mathrm{T}$ \\
\hline 26 & 1,08 & $\mathrm{D}$ & TT & 2,92 & $\mathrm{~B}$ & $\mathrm{~T}$ \\
\hline 27 & 1,38 & $\mathrm{D}+$ & TT & 3,23 & $\mathrm{~B}+$ & $\mathrm{T}$ \\
\hline 28 & 1,23 & $\mathrm{D}+$ & TT & 3,38 & $\mathrm{~B}+$ & $\mathrm{T}$ \\
\hline 29 & 1,23 & $\mathrm{D}+$ & TT & 3,23 & $\mathrm{~B}+$ & $\mathrm{T}$ \\
\hline $\begin{array}{l}\text { Rata- } \\
\text { Rata }\end{array}$ & 1,18 & D & TT & 3,26 & $\mathbf{B}+$ & $\mathbf{T}$ \\
\hline
\end{tabular}

Keterangan:

$$
\begin{array}{ll}
\text { KET } & \text { : Ketuntasan Individual } \\
\mathrm{T} & : \text { Tuntas } \\
\mathrm{TT} & : \text { Tidak Tuntas }
\end{array}
$$

Pada Tabel di atas dapat dilihat bahwa belum ada siswa yang tuntas sebelum pembelajaran berlangsung, setelah dilakukan pembelajaran dengan menggunakan pembelajaran koopertaif tipe NHT berbasis representasi majemuk diperoleh ketuntasan hasil belajar sebesar $100 \%$. Penggunaan model pembelajaran kooperatif tipe NHT memunculkan kesadaran siswa untuk saling membagi informasi melalui berpikir bersama yang merupakan fase ketiga dari sintaks NHT. Seperti yang dikemukakan Piaget faktor utama yang mendorong perkembangan kognitif seseorang adalah motivasi atau daya diri individu itu sendiri untuk mau belajar dan berinteraksi dengan lingkungan (Slavin, 2008).

Keefektifan penggunaan representasi majemuk terhadap pembelajaran kimia didukung oleh penelitian yang sudah dilakukan sebelumnya yakni oleh Herawati (2013) hasil penelitiannya menunjukkan adanya peningkatan penguasaan konsep dan hasil belajar lebih tinggi setelah melakukan pembelajaran berbasis multiple representasi.

\section{Ketuntasan Aspek Sikap}

Hasil belajar yang diamati dalam proses pembelajaran ini terdiri atas sikap spiritual dan aspek sosial. Aspek spiritual yang dikembangkan peneliti meliputi mengagumi keteraturan ikatan kimia dan religius, sedangkan untuk aspek sikap sosial meliputi kerjasama, tanggung jawab dan terbuka. Hasil analisis 
sikap spiritual dan sikap sosial siswa ditunjukkan pada Tabel 4.

Tabel 4. Analisis Ketuntasan Sikap Siswa

\begin{tabular}{|c|c|c|c|c|c|}
\hline \multirow{2}{*}{ No. } & \multicolumn{2}{|c|}{ Sikap Spiritual } & \multicolumn{2}{c|}{ Sikap Sosial } & \multirow{2}{*}{ Ketuntasan } \\
\cline { 2 - 5 } & Nilai & Predikat & Nilai & Predikat & \\
\hline 1 & 4,00 & SB & 4,00 & SB & Tuntas \\
\hline 2 & 2,67 & B & 4,00 & SB & Tuntas \\
\hline 3 & 4,00 & SB & 4,00 & SB & Tuntas \\
\hline 4 & 4,00 & SB & 4,00 & SB & Tuntas \\
\hline 5 & 4,00 & SB & 2,67 & B & Tuntas \\
\hline 6 & 4,00 & SB & 4,00 & SB & Tuntas \\
\hline 7 & 4,00 & SB & 4,00 & SB & Tuntas \\
\hline 8 & 4,00 & SB & 4,00 & SB & Tuntas \\
\hline 9 & 4,00 & SB & 4,00 & SB & Tuntas \\
\hline 10 & 4,00 & SB & 4,00 & SB & Tuntas \\
\hline 11 & 2,67 & B & 2,67 & B & Tuntas \\
\hline 12 & 4,00 & SB & 4,00 & SB & Tuntas \\
\hline 13 & 4,00 & SB & 4,00 & SB & Tuntas \\
\hline 14 & 4,00 & SB & 4,00 & SB & Tuntas \\
\hline 15 & 4,00 & SB & 4,00 & SB & Tuntas \\
\hline 16 & 4,00 & SB & 4,00 & SB & Tuntas \\
\hline 17 & 4,00 & SB & 4,00 & SB & Tuntas \\
\hline 18 & 4,00 & SB & 4,00 & SB & Tuntas \\
\hline 19 & 4,00 & SB & 4,00 & SB & Tuntas \\
\hline 20 & 2,67 & B & 2,67 & B & Tuntas \\
\hline 21 & 4,00 & SB & 4,00 & SB & Tuntas \\
\hline 22 & 4,00 & SB & 4,00 & SB & Tuntas \\
\hline 23 & 4,00 & SB & 4,00 & SB & Tuntas \\
\hline 24 & 4,00 & SB & 4,00 & SB & Tuntas \\
\hline 25 & 4,00 & SB & 4,00 & SB & Tuntas \\
\hline 26 & 4,00 & SB & 4,00 & SB & Tuntas \\
\hline 27 & 4,00 & SB & 4,00 & SB & Tuntas \\
\hline 28 & 2,67 & B & 2,67 & B & Tuntas \\
\hline 29 & 2,67 & B & 2,67 & B & Tuntas \\
\hline & & & & & \\
\hline
\end{tabular}

Tabel di atas menunjukkan bahwa keseluruhan siswa dinyatakan tuntas dengan kategori sangat baik dan baik. Ketuntasan tersebut dapat terwujud karena sebagian besar indikator penilaian sikap spiritual dan sosial yang dibuat peneliti sudah lama dibiasakan oleh pendidik dalam proses pembelajaran.

\section{E. Ketuntasan Aspek Keterampilan}

Hasil belajar aspek keterampilan kinerja diambil oleh dua pengamat pada saat siswa melakukan kinerja dan pengamatan dilakukan dengan mengisi lembar pengamatan keterampilan siswa pada pertemuan ke tiga. Penilaian kinerja yang dinilai dalam penelitian ini adalah keterampilan menyusun molimod. Hasil analisis keterampilan siswa ditunjukkan pada Tabel 5.

Tabel 5. Analisis Ketuntasan Keterampilan Siswa

\begin{tabular}{|l|l|l|}
\hline No & Nilai Akhir & Predikat \\
\hline 1 & 4,00 & A \\
\hline 2 & 2,67 & B- \\
\hline 3 & 4,00 & A \\
\hline
\end{tabular}

\begin{tabular}{|c|c|c|}
\hline No & Nilai Akhir & Predikat \\
\hline 4 & 4,00 & $\mathrm{~A}$ \\
\hline 5 & 4,00 & $\mathrm{~A}$ \\
\hline 6 & 4,00 & $\mathrm{~A}$ \\
\hline 7 & 4,00 & $\mathrm{~A}$ \\
\hline 8 & 4,00 & $\mathrm{~A}$ \\
\hline 9 & 4,00 & A \\
\hline 10 & 4,00 & $\mathrm{~A}$ \\
\hline 11 & 4,00 & $\mathrm{~A}$ \\
\hline 12 & 4,00 & $\mathrm{~A}$ \\
\hline 13 & 4,00 & $\mathrm{~A}$ \\
\hline 14 & 2,67 & B- \\
\hline 15 & 4,00 & $\mathrm{~A}$ \\
\hline 16 & 4,00 & $\mathrm{~A}$ \\
\hline 17 & 4,00 & A \\
\hline 18 & 4,00 & $\mathrm{~A}$ \\
\hline 19 & 4,00 & $\mathrm{~A}$ \\
\hline 20 & 4,00 & $\mathrm{~A}$ \\
\hline 21 & 4,00 & $\mathrm{~A}$ \\
\hline 22 & 2,67 & B- \\
\hline 23 & 4,00 & $\mathrm{~A}$ \\
\hline 24 & 2,67 & B- \\
\hline 25 & 4,00 & $\mathrm{~A}$ \\
\hline 26 & 4,00 & $\mathrm{~A}$ \\
\hline 27 & 4,00 & $\mathrm{~A}$ \\
\hline 28 & 4,00 & $\mathrm{~A}$ \\
\hline 29 & 4,00 & $\mathrm{~A}$ \\
\hline Rata-rata & 3,82 & \\
\hline
\end{tabular}

Berdasarkan hasil analisis keterampilan pada Tabel di atas menunjukkan bahwa keseluruhan siswa dinyatakan tuntas dengan kategori baik dan sangat baik. Perhitungan penilaian aspek keterampilan dengan capaian optimum, hal ini sesuai dengan permendikbud No 104 tahun 2014.

\section{F. Kendala-Kendala}

Beberapa masalah yang ditimbulkan karena keterbatasan waktu diantaranya adalah guru kurang maksimal dalam menyampaikan informasi, keterbatasan waktu untuk mengerjakan LKS. Solusi yang dilakukan guru untuk menggulangi permasalahan tersebut adalah lebih memperhatikan alokasi waktu dan lebih memaksimalkan pada kegiatan yang lebih penting. Pada pertemuan pertama, guru memerlukan banyak waktu untuk membimbing siswa mengerjakan LKS terutama yang berkaitan dengan penerapan pendekatan saintifik, sehingga terjadi kelebihan alokasi waktu. Oleh sebab itu, pada pertemuan pertama guru perlu memberikan bantuan atau bimbingan kepada siswa, seperti yang dijelaskan pada teori pembelajaran Vygotsky.

Pada pertemuan pertama ada beberapa siswa yang belum percaya diri untuk menyampaikan hasil diskusinya, ataupun untuk bertanya dan mengemukakan 
pendapat, solusi untuk mengatasi masalah ini adalah memotivasi siswa untuk berani tampil dihadapan kelas dan menyampaikan pendapat, tanpa ada rasa khawatir pendapat yang disampaikan benar atau salah.

Perilaku tidak relevan siswa yang menjadi kendala dalam kegiatan pembelajaran diantaranya adalah siswa cenderung membuat mainan dari alat peraga yang digunakan ketika menyusun molimod. Solusi yang digunakan untuk mengatasi masalah itu adalah guru menghimbau untuk menggunakan alat peraga dengan benar dan menjelaskan kegunannya.

\section{KESIMPULAN}

\section{A. Simpulan}

Berdasarkan hasil analisis, diskusi, dan temuan dalam penelitian, maka dapat disimpulkan bahwa perangkat pembelajaran model kooperatif tipe NHT berbasis repersentasi majemuk sudah valid, praktis, dan efektif, sehingga layak untuk meningkatkan hasil belajar siswa.

\section{B. Saran}

1. Dalam menerapkan perangkat pembelajaran ini, guru harus dapat mengelolah waktu selama pembelajaran dengan baik, supaya dapat terlaksana sesuai dengan sintak model pembelajaran kooperatif tipe NHT berbasis representasi majemuk.

2. Model pembelajaran kooperatif tipe NHT berbasis representasi majemuk yang diterapkan harus sesuai dengan materi yang diajarkan untuk mendapatkan hasil yang lebih baik dan bisa menerapkan tiga aspek representasi majemuk yakni: makroskopis, mikroskopis, dan simbolik.

\section{REFERENSI}

Akbar, S. (2013). Instrumen Perangkat Pembelajaran. Bandung: PT. Remaja Rosdakarya.

Farida, I., Liliasari., \& Sopandi, W. (2011). "Pembelajaran Berbasis Web untuk Meningkatkan Kemampuan Interkoneksi Multiple level Representasi Mahasiswa Calon Guru pada Topik Kesetimbangan Larutan Asam-Basa”. Jurnal Chemical. 12 (1) 14-24

Herawati, R.F., Mulyani, S., dan Redjeki, T. (2013). "Pembelajaran Kimia Berbasis Multipel Representasi Ditinjau dari Kemampuan Awal terhadap Prestasi Belajar Laju Reaksi Siswa SMA Negeri 1 Karanganyar Tahun Pelajaran 2011/2012”. Jurnal Pendidikan Kimia (JPK). 2 (2) $38-43$.

Kemendikbud. (2013). Permendikbud No.65 tentang Standar Proses Pendidikan dasar dan Menengah. Jakarta: Kemendikbud.

Kemendikbud. (2014). Permendikbud No.104 tentang Pedoman Penilaian Hasil Belajar oleh Pendidik. Jakarta: Kemendikbud.

Laliyo, L. A. R. (2011). “ Model Mental Siswa dalam Mempelajari Perubahan Wujud Zat”. Jurnal Penelitian dan Pendidikan. 8 (1)

Ormrod, J. E. (2008). Psikologi Pendidikan: Membantu Siswa Tumbuh dan Berkembang. Jakarta. Erlangga

Paivio, A. 2006 "Pathways to Literacy Achievement for High Poverty Children," The University of Michigan School of Education

Slavin, R.E. (1994). Educational Psycology Theory and Practice. Sixth Edition. Boston : Allyn and Bacon Publisher

Slavin, R.E. (2008). Psikologi Pendidikan Teori dan Praktik. Jakarta: Indeks

Suyanti, R.D (2010). Strategi Pembelajaran Kooperatif. Medan: Pascasarjana universitas Negeri Medan. 